\title{
Biodegradation of polycyclic aromatic hydrocarbons by a bacterial consortium enriched from mangrove sediments
}

\author{
Mohsen Shahriari Moghadam ${ }^{1,2^{*}}$, Gholamhossein Ebrahimipour ${ }^{3}$, Behrooz Abtahi', Alireza Ghassempour ${ }^{4}$ \\ and Mehri Seyed Hashtroudi ${ }^{5}$
}

\begin{abstract}
Polycyclic aromatic hydrocarbons (PAHs) biodegradation in contaminated sediment is an attractive remediation technique and its success depends on the optimal condition for the PAH-degrading isolates. The aims of the current study was to isolate and identify PAHs-degrading bacteria from surface sediments of Nayband Bay and to evaluate the efficiency of statistically based experimental design for the optimization of phenanthrene (Phe) and Fluorene (Flu) biodegradation performed by enriched consortium. PAHs degrading bacteria were isolated from surface sediments. Purified strains were then identified by $16 \mathrm{~S}$ rDNA gene sequence analysis. Taguchi $L_{16}\left(4^{5}\right)$ was employed to evaluate the optimum biodegradation of Phe and Flu by the enriched consortium. Total of six gram-negative bacterial strains including Marinobacter hydrocarbonoclasticus, Roseovarius pacificus, Pseudidiomarina sediminum and 3 unidentified strains were isolated from enrichment consortium, using Fluorene (Flu) and phenanthrene (Phe) as the sole carbon and energy source. The enriched consortium showed highest degradation abilities (64.0\% Flu and 58.4\% Phe degraded in 7 days) in comparison to a single strain cultures or mixtures. Maximum biodegradation efficiency was occur at temperature $=35^{\circ} \mathrm{C} ; \mathrm{pH}=8$; inoculum size $=0.4 \mathrm{OD}_{600 \mathrm{~nm}}$; salinity $=$ $40 \mathrm{ppt} ; \mathrm{C} / \mathrm{N}$ ratio $=100: 10$. In conclusion our results showed that, indigenous bacteria from mangrove surface sediments of Nayband Bay have high potential to degrade Flu and Phe with the best results achieved when enriched consortium was used.
\end{abstract}

Keywords: Bioremediation, Taguchi experimental design, Soil contamination, PAHs

\section{Introduction}

Mangrove forests are among the most productive coastal ecosystems along the coastline of tropical and subtropical regions. Due to their inherent physical and chemical properties (being rich in organic matter as well as anaerobic and reduced condition of soil) mangrove forests have an extraordinary capacity to accumulate materials discharged to the near shore marine environment [1]. Polycyclic aromatic hydrocarbons (PAHs) are aromatic hydrocarbons with two or more fused benzene rings. The US Environmental Protection Agency (EPA) has identified 16 PAHs

\footnotetext{
* Correspondence: mohsen.mshahriari@gmail.com

'Department of Marine Biology, Faculty of Biological Science, Shahid Beheshti University, G.C, Tehran, Iran

${ }^{2}$ Department of Environment, Faculty of Natural Resources, University of Zabol, Zabol, Iran

Full list of author information is available at the end of the article
}

as particularly important due to their carcinogenic and mutagenic properties [2,3]. Several polluting anthropogenic activities such as oil spilling, incomplete combustion of fossil fuel, ship traffic, urban runoff and industrial activities have led to significant accumulation of PAHs in marine environments especially those near industrial cities $[4,5]$. In essence it is necessary to remove PAHs from environment and to minimize their adverse effects. Microbial degradation is primary mechanism in elimination of PAHs and xenobiotic substances [6]. Numerous investigators have studied the use of mangrove bacteria for biodegradation of PAHs $[7,8]$. In practice, the efficiency of PAH biodegradation can be affected by several factors, such as bacterial population size, temperature, $\mathrm{pH}$, nutrient, salinity, etc. which may be optimized to achieve a more efficient process $[9,10]$.

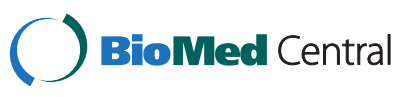

(c) 2014 Shahriari Moghadam et al.; licensee BioMed Central Ltd. This is an Open Access article distributed under the terms of the Creative Commons Attribution License (http://creativecommons.org/licenses/by/2.0), which permits unrestricted use, distribution, and reproduction in any medium, provided the original work is properly credited. 
Conventional optimization procedures are performed by altering one parameter at a time and keeping all other parameters at fixed levels. As a result, the impact of that particular parameter on the process can be assessed. However, these procedures are time consuming, require more experimental data sets and cannot provide information about the mutual interactions of the parameters. Recently, the use of an orthogonal array approach called 'Taguchi method' has been successfully examined in the field microbiological optimization procedures $[11,12]$ which enables one to examine many factors simultaneously and also provides much quantitative information by doing few experimental trials.

The Nayband Bay, as a sensitive coastal region, provides with some ecologically important habitats such as coral reefs, seagrass beds, and mangrove forests. The intensity of industrialization and urbanization began to increase around the area 15 years ago when the South Pars Gas Complex (SPGC) was established and the Assaluyeh harbor was enlarged. Growing industrial activities in the area and their consequent marine polluting effects has threatened different marine habitats in the Nayband Bay in recent years. In essence, the use of practicable and applicable bioremediation protocols for habitat restoration in the area seems mandatory. However, there is little literature on the biodegrading efficacy of PAHs degrading bacteria in the Iranian coasts of Persian Gulf and careful examinations must be done to optimize their operative efficiency. The present study was conducted (1) to isolate the PAHs-degrading bacteria from mangrove sediments; (2) to assess the biodegradation ability of the enriched bacterial consortium and the isolates and (3) to investigate the effects of various factors on the degradation of fluorene (Flu) and phenanthrene (Phe) by enriched consortium using orthogonal experimental design. The study was conducted at Shahid Beheshti University, Iran during 20122013 period.

\section{Materials and methods \\ Collection of sediments}

Aerobic surface sediment samples were randomly collected from the mangrove forests at Nayband bay- Iran, during low tides. Sediment samples were mixed thoroughly to form a composite sample and then sealed into aluminum foils. The sample was transferred to the laboratory and stored at $4^{\circ} \mathrm{C}$ until inoculation time. Physicochemical properties of environmental factors of the sampling area $\left(\mathrm{pH}=8\right.$; temperature $=30^{\circ} \mathrm{C}$; salinity $\left.=40 \mathrm{ppt}\right)$ were measured using $\mathrm{HQ} 40 \mathrm{~d}$ multimeter.

\section{Chemicals}

All solvents (GC gradient grade) and chemicals were purchased from Merck ${ }^{\bullet}$ chemical company. Stock solution of Flu-Phe mix was prepared by dissolving approximately $2 \mathrm{~g}$ of each component in $40 \mathrm{ml}$ acetone. The solutions were stored at $4^{\circ} \mathrm{C}$ for further use.

\section{Enrichment of PAH-degrading bacterial consortium}

In order to enrich PAH-degrading bacterial consortium, predetermined amount of the Flu-Phe mix stock solution was added to a $250-\mathrm{ml}$ conical flask to obtain the final concentration of $1000 \mathrm{mg} \cdot \mathrm{L}^{-1}$. After evaporation of the solvent (acetone), the flask was filled with $45 \mathrm{ml}$ sterilized mineral salt medium (MSM) $\left(1.0 \mathrm{~g} \mathrm{NH}_{4} \mathrm{Cl}, 0.5 \mathrm{~g}\right.$ $\mathrm{K}_{2} \mathrm{HPO}_{4}, 0.01 \mathrm{~g} \mathrm{FeSO}_{4} .7 \mathrm{H}_{2} \mathrm{O}$ in $1 \mathrm{~L} 0.45 \mu \mathrm{m}$ Milliporefiltered $40 \mathrm{ppt}$ local seawater). Then after, approximately, $5 \mathrm{~g}$ of fresh mangrove sediment sample was transferred into the conical flask and adjusted to $\mathrm{pH}=8.0$. The flask was incubated at $30^{\circ} \mathrm{C}$ on a rotary shaker at $140 \mathrm{rpm}$ during of which PAH utilization in the enriched cultures was monitored by a decrease in the amount of $\mathrm{PAH}$ crystals, color changes in the medium (from pale color to dark red), and by increase in bacterial biomass. Then, $5 \mathrm{ml}$ of the enriched culture was transferred to a fresh medium and incubated under the same conditions. This process was repeated for four times to obtain the enriched PAH degrading consortium.

\section{Isolation and identification of bacterial strains}

At the end of the enrichment process, bacterial strains in the consortium were isolated by spreading the 10-fold serially diluted consortium on MSM agar plates coated with a layer of Flu-Phe mix on the surface or on nutrient agar plates ( $3 \mathrm{~g}$ peptone, $5 \mathrm{~g}$ yeast extract, $1.5 \%$ agar in $1 \mathrm{~L}$ of filtered seawater). Then, Bacterial colonies were picked off from the plates, and purified by repetitive streaking onto nutrient agar plates. Purified strains were then identified by biochemical tests such as Gram staining and oxidation/fermentation tests. Further molecular identification of the strains was performed by $16 \mathrm{~S}$ rDNA gene sequences analysis. For this purpose, DNAs of the isolated bacteria were extracted using the bacterial DNA extraction kit (Roche- Germany). The isolated strains were then identified by $16 \mathrm{~S}$ rDNA gene sequence analysis after amplification of the gene by PCR using the set of primers $27 \mathrm{~F}$ (5- AGA GTT TGA TCC TGG CTC AG-3) and 1510R (5-GGT TAC CTT ACG ACT T-3). DNA sequences of the cloned 16S rDNA fragments were compared using BLAST at http://www.ncbi.nlm.nih.gov/ BLAST/ maintained by National Center of Biotechnology Information (NCBI).

\section{Biodegradation of Flu and Phe by enriched consortium and bacterial isolates}

Isolated strains as well as enriched consortium were first cultivated on nutrient agar plates and then transferred on to the MSM $\left(1.0 \mathrm{~g} \mathrm{NH}_{4} \mathrm{Cl}, 0.5 \mathrm{~g} \mathrm{~K}_{2} \mathrm{HPO}_{4}\right.$, $0.01 \mathrm{~g} \mathrm{FeSO}_{4} .7 \mathrm{H}_{2} \mathrm{O}$ in $1 \mathrm{~L}$ of $0.45 \mu \mathrm{m}$ Millipore-filtered 
seawater) supplemented with $1 \%(\mathrm{v} / \mathrm{v})$ light crude oil as the sole source of carbon and incubated for 3 days at $30^{\circ} \mathrm{C}$, at the end of which the cells were collected by centrifugation at $8000 \mathrm{rpm}$ for $15 \mathrm{~min}$, and washed twice in sterilized sea water. To assess the utilization rates of Flu-Phe mix using the above mentioned bacteria, microbial inoculums with final optical density $\left(\mathrm{OD}_{600 \mathrm{~nm}}\right)$ of 0.15 were passed to the following media: (I) $\mathrm{MSM}+$ Flu-Phe mix (II) MSM + Flu-Phe mix + $1 \mathrm{w} /$ $\mathrm{w} \%$ Tween-80. In order to determine the abiotic losses of Flu-Phe mix, the same MSM media without any microbial inoculum were also retained. The experimental cultures were performed in triplicate at $30^{\circ} \mathrm{C}$ in the dark at $140 \mathrm{rpm}$ for 10 days. The entire medium for each trial was used for analysis of the Flu and Phe concentrations.

\section{Optimization of biodegradation ability of enriched consortium}

To maximize Flu and Phe degradation, parameter optimization was done using the Taguchi experimental design, $\mathrm{L}_{16}\left(4^{5}\right)$. The different levels of the studied factors and the layout of the $\mathrm{L}_{16}$ Taguchi's orthogonal array are shown in Table 1 and Table 2. During the optimization process, Flu or Phe were used as a sole carbon source and spiked to the $250 \mathrm{ml}$ conical flask at $500 \mathrm{mg} \cdot \mathrm{L}^{-1}$ concentrations for each. Distilled water and $\mathrm{NH}_{4} \mathrm{Cl}$ were used to adjust the salinity and $\mathrm{C} / \mathrm{N}$ ratio, respectively. In order to reach to the initial inoculum sizes determined by Taguchi experimental design, the enriched consortium was first cultured on MSM supplemented with $1 \%(\mathrm{v} / \mathrm{v})$ light crude oil as the sole source of carbon for 3 days at $30^{\circ} \mathrm{C}$. The cells were then collected by centrifugation at $8000 \mathrm{rpm}$ for $15 \mathrm{~min}$, washed twice in sterilized sea water and used in designed trials. The same experimental setup, without bacterial inoculation, was prepared as a control trials for checking abiotic losses of PAHs. The entire medium of each flask was used for analysis of the Flu and Phe concentrations at $3^{\text {rd }}, 7^{\text {th }}$ and $20^{\text {th }}$ day. All experimental trials $(\mathrm{n}=3)$ were conducted at $140 \mathrm{rpm}$ shaking approach.

\section{Extraction and analysis of Flu and Phe}

The concentration of Flu and Phe were determined according to $\mathrm{Wu}$ et al. [6]. The culture medium was first

Table 1 Combinations of the five factors and four levels on Flu and Phe biodegradation by enriched consortium

\begin{tabular}{lllll}
\hline Factor & \multicolumn{2}{l}{ Level } & & \\
\cline { 2 - 5 } & I & II & III & IIII \\
\hline $\mathrm{pH}$ & 6.5 & 7 & 7.5 & 8 \\
Temperature $\left({ }^{\circ} \mathrm{C}\right)$ & 20 & 25 & 30 & 35 \\
Inoculum size $\left(\mathrm{OD}_{600 \mathrm{~nm}}\right)$ & 0.05 & 0.1 & 0.2 & 0.4 \\
Salinity (ppt) & 25 & 30 & 35 & 40 \\
Carbon/Nitrogen (molar) & $100: 5$ & $100: 10$ & $100: 20$ & $100: 40$ \\
\hline
\end{tabular}

transferred to a $250 \mathrm{ml}$ pre-ash conical flask by addition of $20 \mu \mathrm{L}$ m-terphenyl as internal standard (prepared in acetone with concentration of $1000 \mathrm{mg} \cdot \mathrm{L}^{-1}$ ) and $25 \mathrm{ml}$ ethyl acetate and shacked for $15 \mathrm{~min}$. After separation from the water layer, the organic solvent layer was transferred to a clean conical flask before the second extraction by another aliquot of $25 \mathrm{ml}$ ethyl acetate. Finally, two extracts were combined together, dried by anhydrous $\mathrm{Na}_{2} \mathrm{SO}_{4}$ and the volume was adjusted to $50 \mathrm{ml}$. About $1 \mathrm{ml}$ of the extract sample was transferred into a $1.5 \mathrm{ml}$ brown vial and analyzed by GC-FID .The GC-FID was equipped with a HP-5MS fused silica capillary column $(60 \mathrm{~m} \times 0.25 \mathrm{~mm}$ ID $\times 0.25 \mathrm{~lm}$ thickness, Agilent Technologies, USA) with the injector and detector temperature of $280^{\circ} \mathrm{C}$ and $300^{\circ} \mathrm{C}$, respectively. Nitrogen was used as the carrier gas. The oven temperature program was set as follows: The oven temperature program was from $80^{\circ} \mathrm{C}$ (for $2 \mathrm{~min}$ ) to $120^{\circ} \mathrm{C}$ at a rate of $10^{\circ} \mathrm{C} / \mathrm{min}$ and from $120^{\circ} \mathrm{C}$ to $300^{\circ} \mathrm{C}$ at a rate of $4^{\circ} \mathrm{C} /$ minute and held at $300^{\circ} \mathrm{C}$ for $15 \mathrm{~min}$. The identification and quantification of chemicals were conducted based on matching their retention times of standards [11].

\section{Biodegradation kinetics of fluorene and phenanthrene}

The biodegradation kinetics of Phe and Flu were described using the first order rate model:

$$
C=C_{0} e^{-k t}
$$

where $\mathrm{C}$ is the Phe concentration in the medium at time $t, C_{0}$ is the initial Phe concentration and $k$ is the first order rate constant of reaction.

\section{Biodegradation of Flu and Phe by enriched consortium under different conditions}

Based on the optimal conditions detected from the biodegradation percentages at the end of experiment and first order rate constant (k) of Phe and Flu biodegradation, the consortium was inoculated into sterile $250 \mathrm{ml}$ flasks containing $50 \mathrm{ml}$ of MSM containing $1000 \mathrm{mg} . \mathrm{L}^{-1}$ concentrations of Flu and Phe and residual PAH was determined after 7 days.

\section{Statistical analyses}

Statistica 6.0 was used for designing of the Taguchi experiment. The results were analyzed using factorial ANOVA of the design module in Statistica 6.0 to determine which factor was significant in affecting the percentage and rate of Flu and Phe biodegradation.

\section{Results}

Identification of microbial strains

Six gram-negative bacterial strains were isolated from enrichment consortium (SBU) on nutrient agar plates. 
Table 2 Experimental conditions for Flu and Phe biodegradation based on the orthogonal design form $L_{16}\left(4^{5}\right)$ and results of Flu and Phe biodegradation and first order rate constant $(k)$ at the end of 20-day experiments

\begin{tabular}{|c|c|c|c|c|c|c|c|c|c|c|c|}
\hline \multirow[t]{2}{*}{ EN } & \multirow[t]{2}{*}{$\mathrm{pH}$} & \multirow[t]{2}{*}{ Tem } & \multirow[t]{2}{*}{ Sal } & \multirow[t]{2}{*}{ In } & \multirow[t]{2}{*}{$\mathrm{C} / \mathrm{N}$} & \multicolumn{2}{|c|}{ Final biodegradation $\%$} & \multirow[t]{2}{*}{$k$ of Flu $\left(h-{ }^{1}\right)$} & \multirow[t]{2}{*}{$k$ of Phe $\left(h-{ }^{-1}\right)$} & \multirow[t]{2}{*}{$\mathrm{R}^{2} \mathrm{Flu}$} & \multirow[t]{2}{*}{$\mathrm{R}^{2} \mathrm{Phe}$} \\
\hline & & & & & & Flu & Phe & & & & \\
\hline 1 & 8 & 20 & 25 & 0.05 & $100: 5$ & $16.26 \pm 0.29$ & $16.45 \pm 3.63$ & 0.008 & 0.009 & 0.68 & 0.71 \\
\hline 2 & 8 & 25 & 30 & 0.1 & $100: 10$ & $66.31 \pm 7.02$ & $66.07 \pm 7.19$ & 0.052 & 0.053 & 0.93 & 0.91 \\
\hline 3 & 8 & 30 & 35 & 0.2 & $100: 20$ & $76.35 \pm 5.09$ & $77.00 \pm 3.00$ & 0.070 & 0.070 & 0.91 & 0.90 \\
\hline 4 & 8 & 35 & 40 & 0.4 & $100: 40$ & $92.18 \pm 1.51$ & $89.84 \pm 3.03$ & 0.122 & 0.108 & 0.92 & 0.91 \\
\hline 5 & 7.5 & 20 & 30 & 0.2 & $100: 40$ & $78.08 \pm 5.07$ & $73.88 \pm 8.20$ & 0.080 & 0.072 & 0.98 & 0.98 \\
\hline 6 & 7.5 & 25 & 25 & 0.4 & $100: 20$ & $77.83 \pm 3.50$ & $80.59 \pm 4.51$ & 0.070 & 0.078 & 0.92 & 0.91 \\
\hline 7 & 7.5 & 30 & 40 & 0.05 & 100:10 & $85.68 \pm 7.55$ & $78.74 \pm 4.29$ & 0.103 & 0.078 & 0.99 & 0.96 \\
\hline 8 & 7.5 & 35 & 35 & 0.1 & $100: 5$ & $82.28 \pm 6.06$ & $77.13 \pm 3.72$ & 0.089 & 0.075 & 0.96 & 0.97 \\
\hline 9 & 7 & 20 & 35 & 0.4 & 100:10 & $82.16 \pm 6.29$ & $79.28 \pm 5.59$ & 0.088 & 0.080 & 0.95 & 0.94 \\
\hline 10 & 7 & 25 & 40 & 0.2 & $100: 5$ & $83.82 \pm 4.48$ & $76.53 \pm 6.28$ & 0.094 & 0.075 & 0.97 & 0.98 \\
\hline 11 & 7 & 30 & 25 & 0.1 & $100: 40$ & $87.17 \pm 4.47$ & $80.61 \pm 6.60$ & 0.105 & 0.084 & 0.99 & 0.99 \\
\hline 12 & 7 & 35 & 30 & 0.5 & $100: 20$ & $80.38 \pm 5.62$ & $76.42 \pm 6.41$ & 0.085 & 0.076 & 0.97 & 0.99 \\
\hline 13 & 6.5 & 20 & 40 & 0.1 & $100: 20$ & $47.33 \pm 4.17$ & $46.35 \pm 3.80$ & 0.032 & 0.032 & 0.96 & 0.97 \\
\hline 14 & 6.5 & 25 & 35 & 0.05 & $100: 40$ & $42.13 \pm 3.18$ & $38.71 \pm 5.10$ & 0.026 & 0.025 & 0.95 & 0.98 \\
\hline 15 & 6.5 & 30 & 30 & 0.4 & $100: 5$ & $72.55 \pm 6.67$ & $68.68 \pm 3.56$ & 0.061 & 0.056 & 0.77 & 0.74 \\
\hline 16 & 6.5 & 35 & 25 & 0.2 & $100: 10$ & $73.89 \pm 3.82$ & $69.85 \pm 6.52$ & 0.061 & 0.056 & 0.69 & 0.68 \\
\hline
\end{tabular}

EN, Experiment number; Tem, Temperature $\left({ }^{\circ} \mathrm{C}\right)$; Sal, Salinity (ppt); Optical density $\left(\mathrm{OD}_{600 \mathrm{~nm}}\right) ; \mathrm{C} / \mathrm{N}$, Carbon/Nitrogen (molar).

Among the isolated strains (SBU1- SBU6) only SBU1 showed successfully grown on PAHs MSM plate and turned the color of the plate to the red color after 7 days. Isolated strains were first identified using biochemical tests. Further molecular identification of bacterial strains was performed by amplification and sequencing the $16 \mathrm{~S}$ rDNA and comparing them to the database (Table 3).

\section{Biodegradation of Flu and Phe by enriched consortium} and bacterial isolates

The biodegradation ability of each isolated strain, as well as collaborative efficiency of all six strains and the enriched consortium considering two scenarios: first, by using $1 \mathrm{w} /$ w\% Tween-80 as a surfactant; second, by using surfactant free media are presented in Table 3. In general, the abiotic losses of Flu and Phe during the 7-day biodegradation experiments were negligible and all isolated strains had poor degradation abilities $(<20 \%$ of the Flu and Phe degradation after 7 days). When isolated strains were mixed together, higher Flu and Phe degradation rates were achieved reaching to $16.7 \%$ and $21.4 \%$ for Flu and Phe when Tween-80 was not added and $21.3 \%$ and $24.1 \%$ in the presence of Tween-80, respectively. SBU consortium had highest degradation percentages (Table 3 ).

\section{Biodegradation optimization of Flu and Phe by enriched consortium}

During the Taguchi experiment, the changes in Flu and Phe concentrations in control trials varied between 5 and 29\%. Concentrations of residual PAHs during 20 days experiment are shown in Figure 1. Achieved biodegradation rates of Flu and Phe were fitted by the first order rate

Table 3 Identification of bacterial isolates by 16S rDNA and their growth on Flu and Phe as the sole source of carbon

\begin{tabular}{lllllll}
\hline Isolate & Closest hit & Accession numbers & Flu & Phe & Flu + Tween-80 & Phe + Tween-80 \\
\hline SBU1 & Roseovarius pacificus & KF052989 & 9.2 & 9.9 & 9.6 & 14.3 \\
SBU2 & Marinobacter hydrocarbonoclasticus & KF052990 & 2.6 & 10.6 & 20.6 & 26.0 \\
SBU3 & Pseudidiomarina sediminum & KF052991 & 0.0 & 1.5 & 0.0 & 7.8 \\
SBU4 & Unidentified & - & 5.1 & 3.7 & 6.4 & 15.5 \\
SBU5 & Unidentified & - & 5.3 & 8.9 & 3.0 & 3.8 \\
SBU6 & Unidentified & - & 0.0 & 8.6 & 9.7 & 11.0 \\
Mix of isolated strains & - & - & 16.7 & 21.4 & 21.3 & 24.1 \\
Enrichment consortium (SBU) & - & - & 64.0 & 58.4 & 59.9 & \\
\hline
\end{tabular}




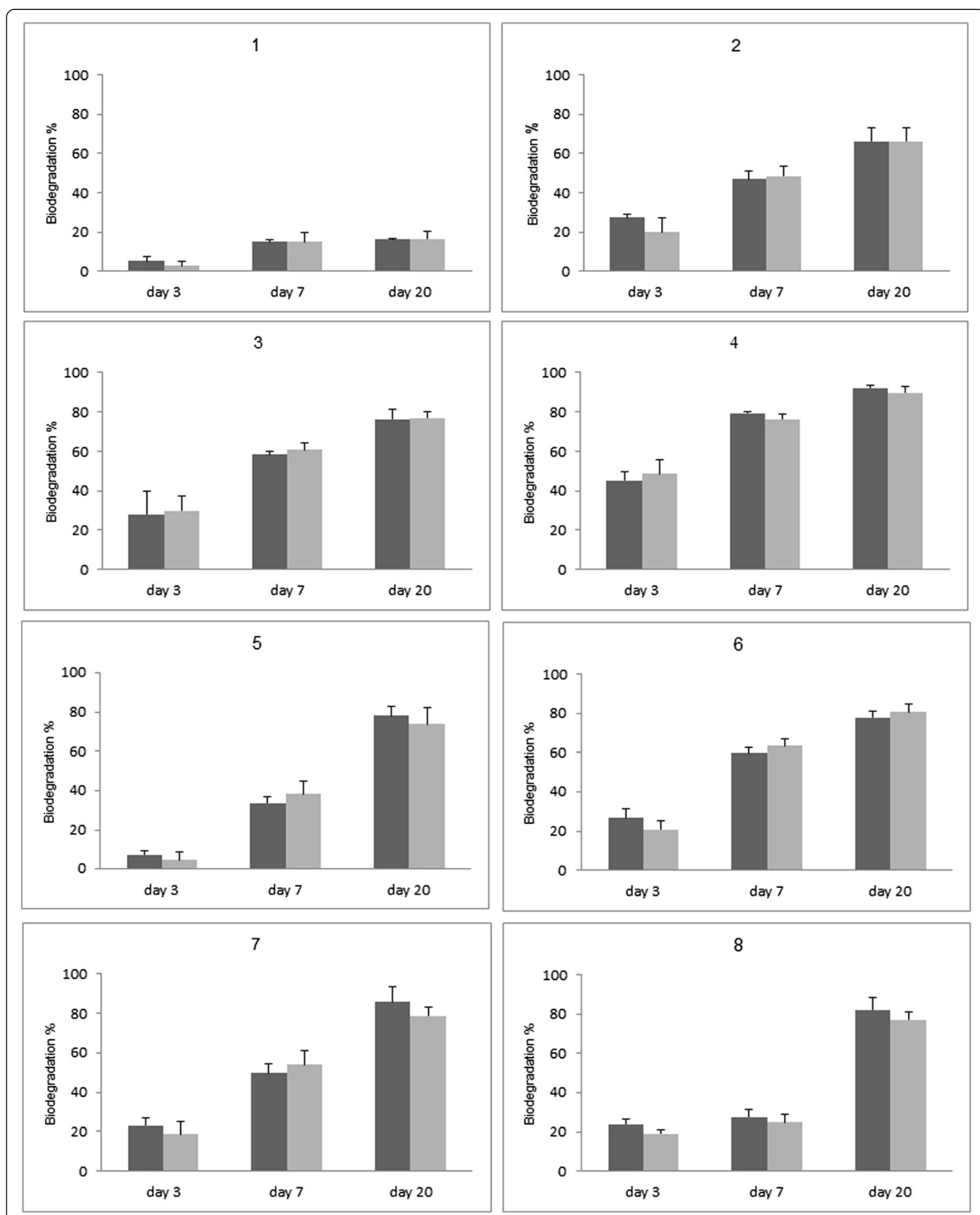

Figure 1 Concentrations of residual PAHs (trials 1-8) during 20 days experiment with the inoculation of enriched consortium (Flu: dark bar, Phe: light bar). 
model with $R_{2}$ values $>0.9$ (Table 2) except in trial numbers 1 (Figure 1), 15, and 16 (Figure 2) which also had the lowest Flu and Phe biodegradation. The degradation percentages and degradation rates $(\mathrm{k})$ in each trial is summarized in Table 2. The highest Flu and Phe biodegradation percentage at the end of $20^{\text {th }}$ day and also the largest first order rate constant were achieved in trial 4 as follows:

1. Degradation percentages (\%) Flu $=92.18 \pm 1.51$; degradation rate $(\mathrm{k}) \mathrm{Flu}=0.122$

2. Degradation percentages (\%) Phe $=89.84 \pm 3.03$; degradation rate $(\mathrm{k}) \mathrm{Phe}=0.108$
On the other hand, the least amount of Flu and Phe biodegradation percentages and first order rate constants were found in trial 1 (Table 2).

\section{Factors affecting biodegradation of phenanthrene and optimal condition}

The ANOVA results of $\mathrm{S} / \mathrm{N}$ ratio comparisons based on the values of the first order rate constants $(\mathrm{k})$ and biodegradation percentages at the end of the 20-day experiment are shown in Table 4. In general, all 5 tested factors had significant effect $(\mathrm{p}<0.05)$ on the biodegradation percentages and the $\mathrm{k}$ values for both Flu and Phe, with the
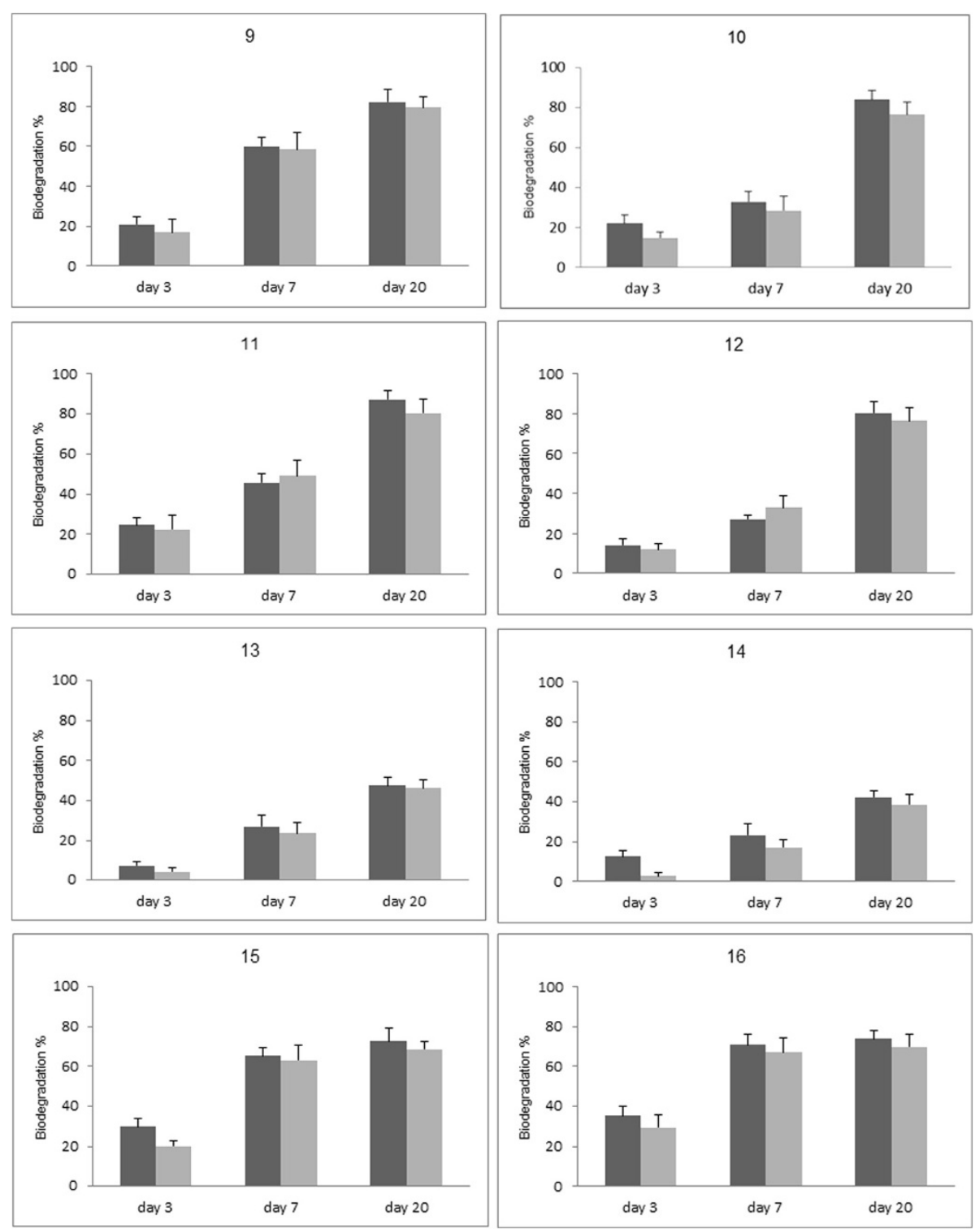

Figure 2 Concentrations of residual PAHs (trials 9-16) during 20 days experiment with the inoculation of enriched consortium (Flu: dark bar, Phe: light bar). 
Table 4 Results of $\mathrm{S} / \mathrm{N}$ ratio comparisons based on the values of the first order rate constants (k) and biodegradation percentages at the end of the 20-day experiment

\begin{tabular}{|c|c|c|c|c|c|c|c|c|c|c|c|c|}
\hline \multirow[b]{2}{*}{ Factors } & \multicolumn{3}{|c|}{$\begin{array}{l}\text { Final biodegradation } \\
\text { (\%) Flu }\end{array}$} & \multicolumn{3}{|c|}{$\begin{array}{l}\text { First order rate constant } \\
\text { (k) Flu }\end{array}$} & \multicolumn{3}{|c|}{$\begin{array}{l}\text { Final biodegradation } \\
\text { (\%) Phe }\end{array}$} & \multicolumn{3}{|c|}{$\begin{array}{l}\text { First order rate constant } \\
\text { (k) Phe }\end{array}$} \\
\hline & $F$ & p-value & Effect size & $F$ & p-value & Effect size & $\mathrm{F}$ & p-value & Effect size & $F$ & p-value & Effect size \\
\hline $\mathrm{pH}$ & 72.93 & 0.00 & 0.0144 & 27.16 & 0.00 & 0.0214 & 52.69 & 0.00 & 9.70 & 21.52 & 0.00 & 11.86 \\
\hline Temperature & 70.98 & 0.00 & 0.0145 & 19.20 & 0.00 & 0.0178 & 53.04 & 0.00 & 9.80 & 14.54 & 0.00 & 10.66 \\
\hline Inoculum & 58.79 & 0.00 & 0.0165 & 9.05 & 0.00 & 0.0138 & 57.99 & 0.00 & 11.09 & 15.34 & 0.00 & 9.66 \\
\hline Salinity & 15.91 & 0.00 & 0.0092 & 7.37 & 0.00 & 0.0161 & 9.98 & 0.00 & 4.36 & 3.67 & 0.02 & 5.73 \\
\hline $\mathrm{C} / \mathrm{N}$ & 16.24 & 0.00 & 0.0082 & 5.49 & 0.00 & 0.0118 & 15.50 & 0.00 & 4.98 & 4.79 & 0.00 & 5.48 \\
\hline
\end{tabular}

inoculum size and $\mathrm{pH}$ as the most effective factors in Flu and Phe biodegradation and first order constant $(\mathrm{k})$ respectively (based on the calculated effect sizes) (Table 4). Theoretically optimized levels for considered factors based on 20-day biodegradation process results or first order constant (k) values were predicted as follows:

1. 20-day biodegradation process (Phe \& Flu) $\mathrm{pH}=7$; temperature $=35^{\circ} \mathrm{C}$; inoculum size OD600 $=0.4$; salinity $=40$ ppt \& $\mathrm{C} / \mathrm{N}=100 / 40$

2. First order constant (K) ${ }_{\text {(Phe \& Flu) }} \mathrm{pH}=7$; temperature $=35^{\circ} \mathrm{C}$; inoculum size ${ }_{\mathrm{OD} 600}=0.4$; salinity $=40$ ppt \& $\mathrm{C} / \mathrm{N}=100 / 10$

Nevertheless, when practical experimental trials based on the above optimized conditions were conducted and compared with the trial 4 (the one with best practical result) both optimized conditions resulted in significantly weaker biodegradation efficiency (Figure 3).

\section{Discussion}

In our study the six bacterial strains isolated from mangrove surface aerobic sediments- Nayband Bay, Iran included Marinobacter hydrocarbonoclasticus, Roseovarius pacificus, Pseudidiomarina sediminum and 3 unidentified strains. PAHs degrading activities of the bacterial consortium belonging to the genus Marinobacter [13,14], and Roseovarius [15,16] have been reported worldwide. In addition, Darmayati et al. [17] isolated Pseudidomarina sp. from oil polluted marine sediments but no PAH degrading abilities were reported previously. Also, Roseovarius pacificus has been isolated from a polycyclic aromatic hydrocarbon $(\mathrm{PAH})$ degrading consortium-deep sea waters of the Indian Ocean, but there is no literature concerning the biodegradation of PAHs by Marinobacter hydrocarbonoclasticus and Pseudidiomarina sediminum.

As confirmed by previous studies [18] addition of Tween-80 to the culture media as a surfactant resulted in increased biodegradation of Flu and Phe by nearly all strains in our study. However addition of Tween-80 had negative effects on biodegradation ability of the SBU5 strain which could be due to strain specific parameters including different toxicity levels of a surfactant and/or competitive utilization of surfactant and PAHs $[19,20]$.

Our enriched consortium performed higher Flu and Phe biodegradation percentage compared with a single strain cultures or all-strain mixture cultures. This could be because of an inappropriate isolation or mixing. On the other hand, several studies have shown that biodegradation caused by mixed culture is more effective than those circumstances when pure cultures are used which may be due to a broader enzymatic capability and counteraction of toxic intermediates by co-metabolic processes $[21,22]$. Also, microbial biodegradation efficiency has been found to depend on other factors. In essence, assessment of the optimal conditions would make the bioremediation process more effective.

In our study, when predicted optimal conditions suggested by models based on biodegradation percentages or first order rate constant $(\mathrm{k})$ were tried, equal removal efficiency for both Phe and Flu were achieved. Interestingly, the biodegradation percentage of trial 4 in Taguchi
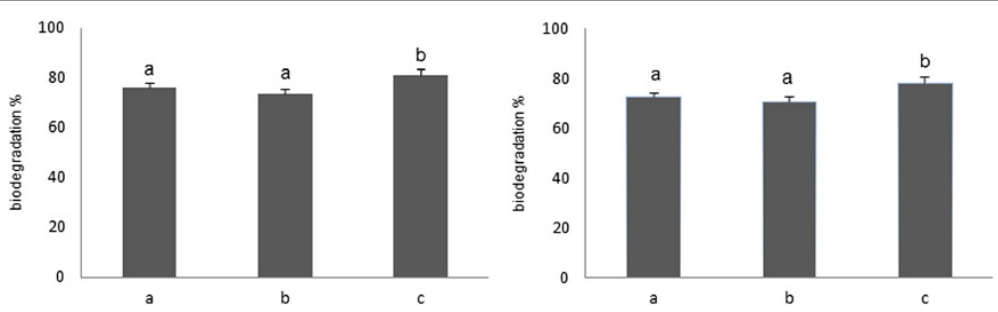

Figure 3 Comparison of Flu (right) and Phe (left) biodegradation efficiency between predicted optimized conditions based on the values of the biodegradation percentages (a) or first order rate constants (b) and Taguchi trial 4 (c). 
design was significantly higher than predicted optimum conditions. Given that, only the $\mathrm{pH}$ was different between trial 4 and predicted optimized conditions, practically optimized levels for $\mathrm{pH}$, inoculums size, salinity, temperature, and $\mathrm{C} / \mathrm{N}$ ratio were adjusted to $8,0.4,35^{\circ} \mathrm{C}$, and $100 / 40$ respectively.

Among environmental variables temperature is one of the most important factors affecting biodegradation of petroleum hydrocarbons [23]. In the current study, the best biodegradation efficiency was achieved when the highest temperature $\left(35^{\circ} \mathrm{C}\right)$ was retained which was also near to the natural conditions where samples were collected. This could be due to the increased solubility of PAHs at higher temperature causing a noticeable improvement in the bioavailability of Flu and Phe molecules $[24,25]$. Also bacterial metabolism may increases as with temperature increase [26].

In terms of salinity, our results proposed 40 ppt salinity as optimum level for Flu and Phe biodegradation which was similar to those levels measured in the Nayband Bay. This may be due to the adaptation of bacteria to environmental conditions. Shiaris [23] found positive correlation between salinity and rates of biodegradation of Phe and naphthalene in estuarine sediment but some researchers reported decreased rates of hydrocarbon metabolism when salinity was increased and concluded that this may be because of negative effects of ions on metabolic rates of bacterial cells [27].

The $\mathrm{pH}$ also has been found to have an important effect on biodegradation. Culture medium $\mathrm{pH}$ can affect microbial diversity and activity possibly through altering the enzymatic activity, transport processes and the nutrient solubility [27]. The biodegradation process was found to be active throughout the $\mathrm{pH}=6-8$ range in the current study and More than $70 \%$ of Flu and Phe was degraded when the $\mathrm{pH}$ of culture medium ranged from 7 to 8 , but the biodegradation percentage was lower in pH 6.5 (about 55\%). Leahy and Colwell [26] have reported that most petroleum degrading bacterial species can perform degrading action at $\mathrm{pH}=6-8$, but the optimum degradation abilities occur near $\mathrm{pH}=7$. Inorganic nutrients have been also suggested to play a key role in the process of PAHs biodegradation and low inorganic nutrient supply has been reported to limit the efficiency of PAH biodegradation in marine environment [28]. The present study supports the above mentioned phenomena by providing evidences for enhanced effects of $\mathrm{N}$ fertilizers on bacterial growth and biodegradation percentages. The molar $\mathrm{C} / \mathrm{N}$ ratio of $100 / 10$ is a generally recommended condition for PAH degradation (based on the average values of elemental microbial cell composition and general microbial crude cellular extract) [11] which is also convenient with our biodegradation percent based predicted model results. However, the
$\mathrm{C} / \mathrm{N}$ ratio for the Taguchi trial 4 as well as first order rate constant $(\mathrm{K})$ based predicted value was 100:40 (molar). Meanwhile, no significant difference was found between biodegradation percentages of both predicted scenario. In this case, supplying the Taguchi trial 4 with 100:10 C/N may also reveal the same result as the 100:40 ratio which can be considered in industrial applications. Finally, the estimated optimum inoculum size was large which may be due to a longer lag phases for smaller inoculums concentrations.

\section{Conclusion}

Our results showed that, indigenous bacteria from mangrove surface sediments of Nayband Bay have high potential to degrade Flu and Phe with the best results achieved when enriched consortium- SBU was used. It can be speculated that although mathematical optimization can improve the biodegradation efficiency of SBU, practically efficient applications may be made with different conditions. Also, successful biodegradation efficiency of a single strain or mixtures may be accomplished during the process of optimization.

\section{Competing interests}

The authors declare that they have no competing interests.

\section{Authors' contributions}

All authors participated to carry out this research and had surveillance on this article and its revisions. All authors read and approved the final manuscript.

\section{Acknowledgment}

The work described was substantially supported by a grant from Pars Oil and Gas Company (POGC) [grant number: 91-212].

\section{Author details}

'Department of Marine Biology, Faculty of Biological Science, Shahid Beheshti University, G.C, Tehran, Iran. ${ }^{2}$ Department of Environment, Faculty of Natural Resources, University of Zabol, Zabol, Iran. ${ }^{3}$ Department of microbiology, Faculty of Biological Science, Shahid Beheshti University, G.C, Tehran, Iran. ${ }^{4}$ Department of Phytochemistry, Medicinal Plants and Drugs Research Institute, Shahid Beheshti University, G.C, Tehran, Iran. ${ }^{5}$ Iranian

National Institute for Oceanography (INIO), Tehran, Iran.

Received: 17 May 2013 Accepted: 26 July 2014

Published: 21 August 2014

\section{References}

1. Tam NFY, Ke L, Wang XH, Wong YS: Contamination of polycyclic aromatic hydrocarbons in surface sediments of mangrove swamps. Environ Pollut 2001, 114:255-263.

2. Baneshi MM, Rezaei Kalantary R, Jonidi Jafari A, Nasseri S, Jaafarzadeh N, Esrafili A: Effect of bioaugmentation to enhance phytoremediation for removal of phenanthrene and pyrene from soil with Sorghum and Onobrychis sativa. J Environ Health Sci Eng 2014, 12:24.

3. Wu YL, Wang XH, Li YY, Hong HS: Occurrence of polycyclic aromatic hydrocarbons (PAHs) in seawater from the Western Taiwan Strait, China. Mar Pollut Bull 2011, 63:459-463.

4. Tam NFY, Wong YS: Effectiveness of bacterial inoculum and mangrove plants on remediation of sediment contaminated with polycyclic aromatic hydrocarbons. Mar Pollut Bull 2008, 57:716-726.

5. Sinaei M, Mashinchian A: Polycyclic aromatic hydrocarbons in the coastal sea water, the surface sediment and Mudskipper Boleophthalmus dussumieri from coastal areas of the Persian Gulf: source investigation, 
composition pattern and spatial distribution. J Environ Health Sci Eng 2014, 12:59.

6. Wu YR, Luo ZH, Vrijmoed LLP: Biodegradation of anthracene and benz[a] anthracene by two Fusarium solani strains isolated from mangrove sediments. Bioresour Technol 2010, 101:9666-9672.

7. Chang BV, Chang IT, Yuan SY: Anaerobic degradation of phenanthrene and pyrene in mangrove sediment. Bull Environ Contam Toxicol 2008, 80:145-149.

8. Li CH, Wong YS, Tam NFY: Anaerobic biodegradation of polycyclic aromatic hydrocarbons with amendment of iron (III) in mangrove sediment slurry. Bioresour Technol 2010, 101:8083-8092.

9. Carmichael LM, Pfaender FK: The effect of inorganic and organic supplements on the microbial degradation of phenanthrene and pyrene in soils. Biodegradation 1997, 8:1-13.

10. Simarro R, González N, Bautista LF, Molina MC, Schiavi E: Evaluation of the influence of multiple environmental factors on the biodegradation of dibenzofuran, phenanthrene, and pyrene by a bacterial consortium using an orthogonal experimental design. Water Air Soil Pollut 2012, 223:3437-3444.

11. Chen J, Wong MH, Wong YS, Tam NFY: Multi-factors on biodegradation kinetics of polycyclic aromatic hydrocarbons (PAHs) by Sphingomonas $s p$. , a bacterial strain isolated from mangrove sediment. Mar Pollut Bull 2008, 57:695-702.

12. Tripathi AD, Srivastava SK: Novel approach for optimization of fermentative condition for polyhydroxybutyrate (PHB) production by Alcaligenes sp. Using Taguchi (DOE) methodology. Afr J Biotechnol 2011, 10:7219-7224.

13. Cui Z, Lai Q, Dong C, Shao Z: Biodiversity of polycyclic aromatic hydrocarbon-degrading bacteria from deep sea sediments of the Middle Atlantic Ridge. Environ Microbiol 2008, 10:2138-2149.

14. Gao W, Cui Z, Li Q, Xu G, Jia X, Zheng L: Marinobacter nanhaiticus sp. nov., polycyclic aromatic hydrocarbon-degrading bacterium isolated from the sediment of the South China Sea. Antonie Van Leeuwenhoek 2013, 103:485-491.

15. Vila J, María Nieto J, Mertens J, Springael D, Grifoll M: Microbial community structure of a heavy fuel oil degrading marine consortium: linking microbial dynamics with polycyclic aromatic hydrocarbon utilization. FEMS Microbiol Ecol 2010, 73:349-362.

16. Lai Q, Zhong H, Wang J, Yuan J, Sun F, Wang L, Zheng T, Shao Z: Roseovarius indicus sp. nov., isolated from deep-sea water of the Indian Ocean. Int J Syst Evol Microbiol 2011, 61:2040-2044.

17. Darmayati Y, Harayama S, Yamazoe A, Hatmanti A, Sulistiani, Nuchsin R, Kunarso DH: Hydrocarbonoclastic bacteria from Jakarta Bay and Seribu Islands. Mar Res Indones 2008, 33:55-64

18. González N, Simarro R, Molina MC, Bautista LF, Delgado L, Villa JA: Effect of surfactants on PAH biodegradation by a bacterial consortium and on the dynamics of the bacterial community during the process. Bioresour Technol 2011, 102:9438-9446.

19. Laha S, Luthy RG: Effects of nonionic surfactants on the solubilization and mineralization of phenanthrene in soil water systems. Biotechnol Bioeng 1992, 40:1367-1380.

20. Liu Y, Zhu L, Shen X: Polycyclic aromatic hydrocarbons (PAHs) in indoor and outdoor air of Hangzhou, China. Environ Sci Technol 2001, 35:840-844.

21. Sugiura K, Ishihara M, Shimauchi T, Harayama S: Physicochemical properties and biodegradability of crude oil. Environ Sci Technol 1997, 31:45-51.

22. Casellas M, Grifoll M, Sebate J, Solanas AM: Isolation and characterization of a fluorene-degrading bacterial strain and its role in synergistic degradation of fluorene by a consortium. Can J Microbiol 1998, 44:34-742.

23. Shiaris MP: Seasonal biotransformation of naphthalene, phenanthrene, and benzo[a]pyrene in surficial estuarine sediments. Appl Environ Microbiol 1989, 55:1391-1399

24. Mohn WW, Stewart GR: Limiting factors for hydrocarbon biodegradation at low temperature in Arctic soils. Soil Biol Biochem 2000, 32:1161-1172.

25. Margesin R, Schinner F: Biodegradation and bioremediation of hydrocarbons in extreme environments. Appl Microbiol Biotechnol 2001, 56:650-663.
26. Leahy JG, Colwell RR: Microbial degradation of hydrocarbons in the environment. Microbiol Rev 1990, 54:305-315.

27. Lin C, Gan L, Chen ZL: Biodegradation of naphthalene by strain Bacillus fusiformis (BFN). J Hazard Mater 2010, 182:771-777.

28. Breedveld GD, Sparrevik M: Nutrient limited biodegradation of PAHs in various soil strata at a creosote contaminated site. Biodegradation 2000, 11:391-399.

doi:10.1186/s40201-014-0114-6

Cite this article as: Shahriari Moghadam et al:: Biodegradation of polycyclic aromatic hydrocarbons by a bacterial consortium enriched from mangrove sediments. Journal of Environmental Health Science \& Engineering 2014 12:114.

\section{Submit your next manuscript to BioMed Central and take full advantage of:}

- Convenient online submission

- Thorough peer review

- No space constraints or color figure charges

- Immediate publication on acceptance

- Inclusion in PubMed, CAS, Scopus and Google Scholar

- Research which is freely available for redistribution

Submit your manuscript at www.biomedcentral.com/submit
() Biomed Central 